\title{
EGFL6 wt Allele
}

National Cancer Institute

\section{Source}

National Cancer Institute. EGFL6 wt Allele. NCI Thesaurus. Code C54439.

Human EGFL6 wild-type allele is located within Xp22 and is approximately 64 kb in length.

This allele, which encodes EGF-Like Protein 6, is involved in cell cycle. 